\title{
What Jihad Questions Do Muslims Ask?
}

\author{
Emad Mohamed and Bakinaz Abdalla
}

\begin{abstract}
Using digital humanities tools and methods, we extract, classify, and analyze 1,006 jihad fatwas from a corpus of 164,000 online fatwas. We use the questions and page hits to rank clusters of fatwas in order to discover what jihad questions Muslims ask, what jihad issues interest Muslims the most, and what the targets of jihad may be. We focus more on the questions than the answers, since it is the questions that give us a window into what may be called the "Muslim collective mind." The results show that jihad questions are interwoven with several key topics, from performance of prayers to expiation for homosexuality. While the Prophet Muhammad's military expeditions were the most asked about and most viewed category, since they provide a model of what jihad is, the second most important category was concubinage. When there was a specific target, Jews were found in $73 \%$ of the questions.
\end{abstract}

Keywords: Jihad, Fatwa, Concubinage, Dhimmi, Digital Humanities

\section{Introduction}

The root $j-h-d$, from which the word jihad is derived, is used in the Qur'ann in 36 verses that urge the believers to exert effort in the cause of Allah. In his study of jihad in the Qur'ān, ElSayed Amin explains, "the one who exercises jihad struggles to overcome his evil inclinations, whether fighting the enemy

Emad Mohamed is a visiting assistant professor of linguistics at Indiana University, Bloomington, IN. Mohamed's main interests are computational linguistics, Arabic linguistics and the combination thereof. $\mathrm{He}$ is especially interested in how Natural Language Processing (NLP) can help provide deeper insights into the humanities, and has recently focused on NLP applications to Islamic studies, Qur'ānic studies, and sociology. Mohamed's most recent publications include: "Jewish, Christian, and Islamic in the English Wikipedia" (Heidelberg Journal of Religions on the Internet) and "Ara aytum: the Exegetical Implications of a Qur'ānic Stance Marker” (Al-Bayan Journal for Qur'ān and Hadith Studies, forthcoming).

Bakinaz Abdalla earned her M.A. degree in Near Eastern studies, Indiana University, and is a Ph.D. candidate in Jewish studies at McGill University, Montreal, Canada. Her Ph.D. thesis "One Truth or Two? The Case of Isaac Albalag" discusses how medieval Muslim and Jewish philosophers responded to the question of the relation of religion to philosophy. Abdalla will be a postdoctoral researcher at the Maimonides Center for Jewish Skepticism (Hamburg University, Germany) in 2018, where she will continue her work on Medieval Jewish philosophy. 
on the battlefield, verbally by enjoining good and forbidding evil in society, or controlling one's illicit wants and desires." The term jihad was generic enough that when Muslim philosophers started adapting Greek philosophy, "the struggle to convert the world to the rule of philosophy and the sovereignty of reason was called jihad."

Ibn Qayyim al-Jawziyya ${ }^{3}$ maintains that there are four types of jihad: jihad against the self, jihad against the Devil, jihad against the disbelievers, and jihad against the hypocrites. However, "The overwhelming majority of classical theologians, jurists, and traditionists understood the obligation of jihad in a military sense and have examined and expounded it accordingly." It is only natural, then, that jihad in the West has been more associated with the military sense of the term as evidenced by the Oxford English Dictionary's definition of jihad: "a war or struggle against unbelievers." The most generic use of the term in modern-day Arabic also carries the sense of warfare, while other uses have to be qualified, such as jihad al-nafs: jihad against the self. In this study, when we ask the question, "What jihad question do Muslims ask?" we will limit our definition of jihad to the concept of war and exclude all the other categories.

The study of jihad is important for various reasons. Wael B. Hallaq notes:

In the entire repertoire of legal concepts, there is today no more ambiguous and multilayered term than jihad. The concept is charged with religious, legal, cultural, and political connotations, and has proved to be even more controversial than such concepts and practices as polygamy. Its potential and outward militancy invariably provokes hostile reactions from Western observers, even when they are in full cognizance that jihad is a theory that belongs to the past. ${ }^{6}$

However, while jihad may be "a theory that belongs to the past," it is still alive in Muslim and non-Muslim minds. A study of the most important associations of the term "Islamic," on the English Wikipedia finds that some of the chief cognates include terrorism, fundamentalism, militant, extremism, extremist, terrorist, fundamentalist, conqueror, fascism, fighter, resistance, rebellion, warrior, expansion, and attack, all of which are related to the concept of jihad. ${ }^{7}$ According to Langview's Analysis, ${ }^{8}$ the Wikipedia page "Jihad" had an average of 6,253 page views per day in the period from May 1, 2016 to July 31, 2016. Moreover, according to the Pew Research Center, in 2015, the page on The Islamic State of Iraq and the Levant (ISIL/ISIS) was the fourth most viewed article on the English Wikipedia, the sixth most viewed article on the German Wikipedia, and the second most viewed page on the French Wikipedia. These are important indications of how currently relevant the topic of jihad is. ${ }^{9}$

In spite of the widely perceived importance of jihad, so far there has been little study of the jihad questions that most interest Muslims, although such 
a study could provide "unique windows into the projects, desires, and fears of Muslim individuals and communities." ${ }^{10}$ Gary R. Bunt has studied limited aspects of the jihad issue online, but his study is now outdated. Furthermore, it does not provide concrete statistics or measures of relative importance. ${ }^{11}$ In a more recent study, G. Weinmann has investigated fatwas on jihad. This author discusses the questions of legitimate targets, legitimate actions, the legitimacy of suicide bombing, paying zakat to the mujahidin, the use of weapons of mass destruction, and fatwa disputes online. He also discusses the fatwas issued by Yusuf al-Qaradawi on martyrdom operations. However, he only analyzes a limited number of fatwas (fewer than ten). ${ }^{12}$ In addition, the focus of study has been on approaches to jihad and answers provided by Islamic scholars. The focus of the present study, however, is on the questions about jihad. Our contention is that while the answers of scholars provide information on the classical theory of jihad, a focus on the questions that are asked can give better insight into how ordinary Muslims think about jihad.

\section{Two Theories of Jihad}

Among Islamic scholars, one can find two theories of jihad: (1) jihad as offensive war, and (2) jihad as defensive war. The Offensive Jihad theory divides the world into two abodes: the Abode of Islam (dar al-islām) and the Abode of War (dar al-harb). According to this theory, "the natural and permanent relationship between the world of Islam and the world of the unbelievers was one of open or latent war, and there could, therefore, be no peace and no treaty." ${ }^{13}$ Perhaps the most prominent representative of this theory is Ibn Taymiyyah, ${ }^{14}$ who wrote, "The aim behind fighting is for the religion [of Islam] to become dominant and for the Word of God to reign supreme. Whoever refuses to adopt Islam is to be fought against according to the consensus of the Muslims." ${ }^{15}$ Other figures supporting this theory are Ibn Qayyim al-Jawziyyah, Abu al-Ala' Mawdudi, and Sayyid Qutb, all of whom were influenced by Ibn Taymiyyah. The Defensive Jihad theory maintains that the purpose of jihad is to defend the Muslim nation, and wars of expansion or offensive wars against others are not justified. The most prominent scholars in support of this theory are Abu Salamah b. Abd al-Rahman (d. 94 AH/712 CE or 104 AH/722 CE), and Sufyan al-Thawri (d. $161 \mathrm{AH} / 777 \mathrm{CE}$ ) in the early Islamic period, ${ }^{16}$ and Muhammad 'Abduh, ${ }^{17}$ Rashid Rida, ${ }^{18}$ and Darwazah in the modern period. Each of these camps bases their theory of jihad on a particular understanding of the Qur'an and the Prophetic traditions. ${ }^{19}$ Other recent supporters of the Defensive Jihad theory are Mahmoud Shaltout (1893-1963) and Muhammad Abu Zahrah (1898-1974). Shaltout wrote, "The only reasons for fighting in the Qur'ān are blocking aggression, protecting the faith, and the freedom of religion." ${ }^{20}$ 
In the present article, we provide a quantitative analysis of 1,006 jihad questions extracted from a corpus of 164,000 online fatwas, with the purpose of providing some answers to the following questions:

- What jihad questions do Muslims ask?

- Which of these questions are most important for Muslims?

- Which groups of people or regions are the subjects of these questions: Jews, Christians, Israel, Kashmir, etc.?

The rest of this article will proceed as follows: Section Two introduces the data and methods of analysis, Section Three discusses the results of the survey, and Section Four wraps up the investigation with a conclusion and summary of the findings.

\section{Data}

Before discussing the data and methods, it may be useful to define what a fatwa is. As expressed online, a fatwa is basically a question and answer. When a Muslim has a question (usually about religious matters, but it can be about anything), he directs that question to a Muslim who is believed to be a scholar or jurisconsult. The scholar/jurisconsult then issues a response in the form of an opinion (fatwa) to the questioner. In Arabic, the questioner is known as a mustafti and the scholar/jurisconsult is known as a mufti. The data for this study comes from a popular online fatwa bank: Islam Web Fatwa Center (henceforth IWFC). The IWFC is part of IslamWeb, which is owned and managed by the Ministry of Islamic Affairs of the State of Qatar. The choice of the IWFC for this study was based on the following reasons:

1. The IWFC is one of the most popular fatwa centers online. In spite of being Qatari-owned, only 3.5\% of the website visitors come from Qatar. Of the rest, 27.5\% come from Egypt, 23.3\% come from Saudi Arabia, 11.3\% come from Algeria, and 6.2\% come from Morocco. In Egypt, the website ranks 134 among the top-visited web sites. The website ranks 139 in Saudi Arabia, and in both Egypt and Saudi Arabia it is the most visited Islamic website. ${ }^{21}$ In our examination of jihad questions on this site, we also found questions from Europe and North America. The fact that Muslims from different geographical locations trust the website provides a well-represented sample, thus giving the results a measure of reliability.

2. The IWFC is the largest fatwa bank available. To the best of our knowledge, the IWFC is the largest fatwa bank online. A major competitor, the Egyptian Fatwa House, has only around 3,000 fatwas on its website. Islam Online (http://fatwa.islamonline.net), a major Islamic website, only has 3,254 
fatwas as of January 31, 2016. The IWFC, by contrast, has 165,537 fatwas online, spanning the period from 1999 to the end of 2015 , with an average of 9,737 fatwas every year for a total period of 17 years. The Muslims who post questions to this website, and those who read it, thus represent a significant sample of the online Muslim population. The more data we can access, the closer we get to a plausible portrayal of Muslim concerns and interests.

3. The IWFC has rich metadata. Metadata is a term that means "data about the data." Each fatwa on the website has enough data to describe it and make it useful for research. For each fatwa on the IWFC, there is metadata about the fatwa date, which usually is only a few days after the question is asked. Data on the availability of time indicators can help us track the trends of fatwas over time. Most fatwas are also topic-classified. For example, a fatwa may be classified under the topic, Financial questions $\rightarrow$ Sale $\rightarrow$ Sale of alcohol. This classification can help us track certain topics and interests. The IWFC also keeps a count of page hits, or how many times a certain fatwa has been visited. This helps us assess the popularity of certain fatwas, and certain topics and subtopics from the reader's perspective.

4. The IWFC is keen on privacy. The IWFC receives questions through a web form. The questioner types a question, fills in some information, and hits ENTER. None of the information is shared with others. This is very significant as privacy encourages people to ask questions they would otherwise refrain from asking. For example, one of the most popular fatwas on the IWFC web site is one that asks whether oral sex is permissible in Islam. As of the writing of this paper, this fatwa has been read over 1,100,000 times.

Figure 1 shows the distribution of IWFC fatwas over the 17 years of activity. From this chart, we can see that the number of fatwas jumped quickly from a modest beginning in 1999 (984 fatwas), to 13,654 fatwas in 2004. The IWFC seems to have had a stable trend in the number of fatwas since that time.

In presenting the answers to jihad questions, we will mainly be interested in quantitative analysis. While we may quote fatwas or focus on certain aspects of questions or answers from the website, due to the limited scope of this study and space limitations, we will mostly refrain from delving into the details of legal and religious arguments.

It is important to stress once again that in this study we are more interested in the jihad questions than in the answers given to them. Overall, the IWFC follows the Offensive Jihad theory, as based on our analysis of the answers. This is also apparent through analysis of the authorities consulted and in the references 


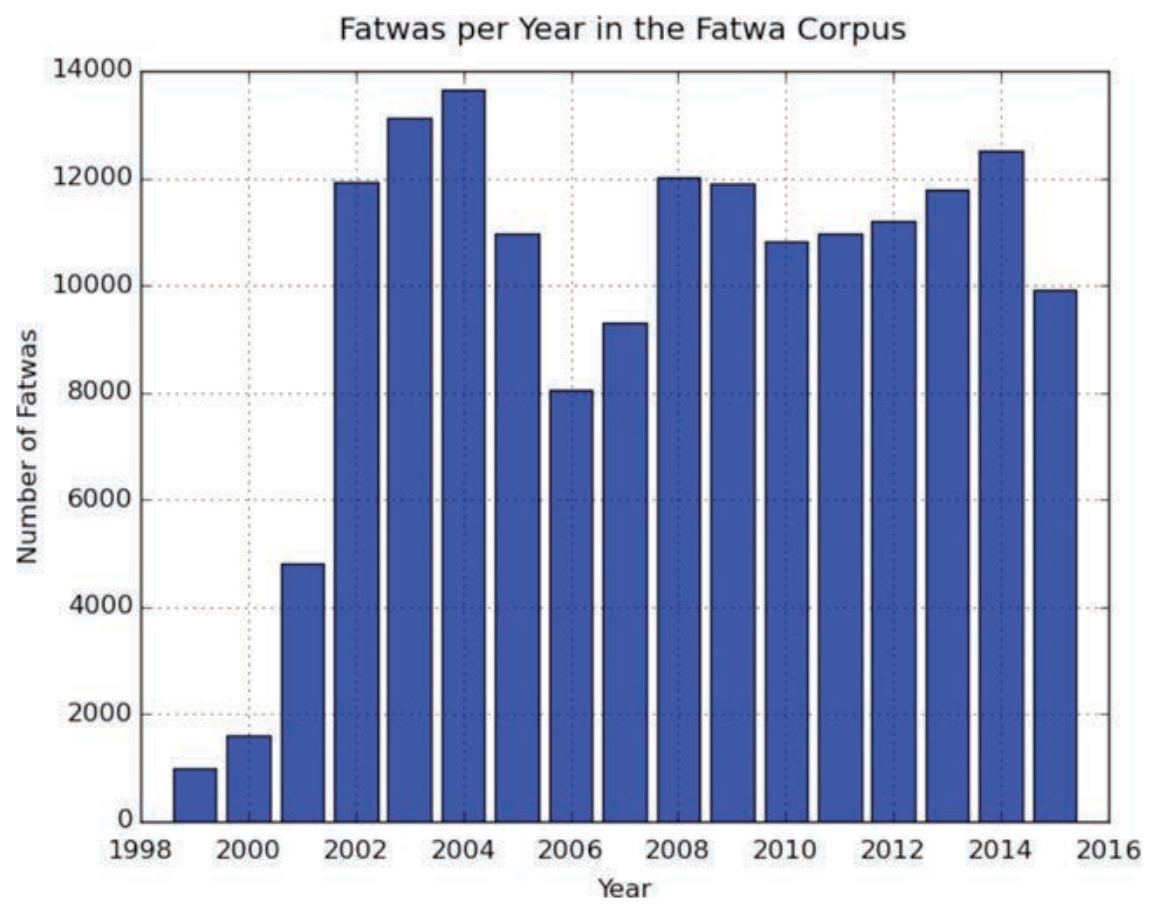

Figure 1: Fatwa numbers in 17 years.

they use in supporting their answers. The scholars most frequently cited in the answers to jihad questions are: Ibn Taymiyyah, Ibn Qayyim, and Ibn Qudamah, who are all supporters of the Offensive Jihad theory. The Defensive Jihad Theory seems to be missing completely from the IWFC answers, and Muhammad 'Abduh, the main exponent of this theory, is portrayed very negatively by the scholars/muftis of the IWFC. By contrast, The Egyptian Fatwa House website, gives much greater support to the Defensive Jihad theory. However, their website has only 32 jihad-related fatwas. ${ }^{22}$

With respect to the jihad questions, those referred to on The Egyptian Fatwa House website, as well as those referred to on other websites such as Islamqa.info (another large fatwa bank), are much the same as those referred to by the IWFC. It is worth mentioning as well that Qatar's IslamWeb has fatwa websites in both Arabic and English. We have focused our analysis on the Arabic site since this is where most of the jihad questions are asked. The English website has only 27 jihadrelated questions, and each of these has several counterparts on the Arabic website.

\section{Methods}

The fatwas on the IWFC website are available in html format. While html is great for online viewing, for analytical purposes, all that is needed are the 
raw texts of the fatwas. We extracted the main items of information from the fatwas (title, question, answer, Qur'ān references, scholars cited, number of views, etc.), and then performed a cleaning process, which involved separating out punctuation and removing diacritics. The purpose of this cleaning was to make the search process easier, since a single Arabic word may be written in several different forms.

Once the text processing operation was done, the fatwas then went through a process of re-classification. In spite of the fact that the fatwas are supposedly classified according to topic, we found 6,007 fatwas without any classification. To overcome this problem, we used two different methods to re-classify the unclassified fatwas: (1) if the unclassified fatwas contained links to other, classified, fatwas, we assigned to them the topic of the first cited fatwa; (2) if no other fatwas were cited, we assigned to the fatwa the topic of the most comparable fatwa that had a topic classification. We used the technique of topic modeling to find similarities between fatwas. ${ }^{23}$

With the fatwas now classified by topic, we next grouped them together under topic clusters, with some manual intervention. Each cluster contained fatwas that had more or less the same theme. One theme, for example, was war spoils, and another was concubinage. To determine which of these themes was more important, we tallied the number of views or page hits. The importance of a certain category, like concubinage, was based on the number of views that all the fatwas in the same category received. We use a modified $\mathrm{z}$-score analysis ${ }^{24}$ to detect and remove outliers, and ranked the categories accordingly. For example, if a category had five fatwas with views numbering $11,000,1,000,900,1,230$, and 875 , respectively, the modified z-score could detect that 11,000 was an outlier. Therefore, we would remove it and add up the sum of the other views to get the category score $(1000+900+1230+875=4005)$. The category with the highest score was deemed the most important category for analytical purposes.

Using views rather than the raw number of questions allows us to better measure the potential societal importance of a particular category. For example, a question that is viewed a million times obviously has more potential societal importance than one that is viewed only a thousand times.

\section{Results and Discussion I: What Jihad Questions Do Muslims Ask and Which Questions Are Most Important?}

We extracted 1,006 questions about jihad from the IWFC corpus. Jihad questions can be found under many categories, and it is sometimes difficult to adopt a single classification for them. For example, under the category of family law, one question raised the issue of marriage for a woman whose husband was missing in action, how long should she wait for him to return, when should he be considered dead, and what would be the consequence if she got married to 
someone else and then her missing husband turned out to be alive (ID: 9041). ${ }^{25}$ Under the vows category, a father asked: "I made a vow to dedicate my child to jihad. How can I actualize this, and will I, or he, be punished by God if we do not fulfill this vow?" (ID: 79495). Under the entertainment category, a questioner asked about the permissibility of playing a computer game in which the gamer plays the role of an American soldier who fights terrorism in Muslim countries such as Pakistan or Iraq. The questioner wonders, "Will I be an unbeliever (kafir) if I play this game? Is fighting against Muslims in virtual reality the same as fighting against Muslims in reality?” (ID: 183665). Because the concept of jihad interacts with so many aspects of Muslim life, it was necessary to be selective in the number of categories assessed. Table 1 contains a classification of the top 30 jihad categories in our corpus. Only the categories in bold will be discussed in this article (some more extensively than others). The reason for this is while all the categories are relevant to the subject of jihad, some are of more general interest than others. The top 30 categories in Table 1 cover $90 \%$ of the total number of views (page hits), and $75 \%$ of the jihad questions asked. The topics discussed below are ranked in descending order, according to the total number of views tallied on the IWFC website.

\section{(1) The Prophet's Wars}

Although the "Prophet Muhammad never formally declared a jihad - not, at least, using that term - yet the many campaigns that he undertook on behalf of his faith are the prototypical jihad wars."26 Thus, it is not surprising to find that most jihad questions and most interest focus on the Prophet's wars. The 159 fatwas on this topic receive $22.8 \%$ of the total views. Readers are interested in knowing more about the Prophet's history and his wars. Ranked by number of views, the most important subtopics in this category are the Battle of Badr, the Battle of Uhud, the Battle of Tabuk, the incident of ifk (in which the Prophet's wife 'Aisha was slandered), the Battle of Mu'tah, the Battle of the Trench, the Battle of Banu Qurayzah, and the Battle of Khaybar. Although the fatwas on Banu Qurayzah and Khaybar are among the least viewed in this category, they carry special significance today because they are typically consulted in the context of relations between Muslims and Jews. There are six jihad fatwas in which a questioner mentioned Banu Qurayzah.

\section{(2) Concubines and Prisoners of War}

This is the second most viewed category of jihad questions, with 116 questions and $17.38 \%$ of the total number of views. Classical jihad literature maintains that a woman captured in battle is enslaved, and that if she is unmarried, or if she is married but her husband is not captured with her, she becomes "sexually lawful to her master." ${ }^{27}$ Furthermore, "According to Islamic law, concubines, like slaves 
in general, had to be of non-Muslim origin, on the basis that they were legitimate booty from holy war."28 A concubine who bore a child gained special status as an umm walad, and many concubines reached powerful positions in Islamic history. Abu Zahara explains that while the Qur'ān did not directly condone slavery, it was allowed, and it became a widespread practice as the Muslim state turned into an empire. Muslims imitated the other empires of the time, which practiced the enslavement of battlefield captives. ${ }^{29}$

While until very recently the enslavement of captives and concubinage were merely historical questions in most of the modern Muslim world, the Islamic State in Iraq and Syria (ISIS) and Boko Haram have revived these practices. ISIS reportedly "abducted 5,270 Yazidi girls and women ... who were subsequently forced into sexual slavery." ${ }^{\prime 30}$ Several reports have been published about the group's sex slaves and their claim that such practices are part of their revival of the true religion of Islam. ${ }^{31}$ However, questions about the enslavement of captives and concubinage on the IWFC website pre-date the establishment of these groups.

Table 1: Jihad Question Categories. Categories Ranked by Number of Adjusted Views

\begin{tabular}{|c|c|c|c|c|c|c|}
\hline & Aviews & Views & $\%$ & Count & Cum\% & Category \\
\hline 1 & 1210432 & 1957403 & 22.8 & 159 & 22.8 & The Prophet's Wars \\
\hline 2 & 680728 & 1492407 & 17.38 & 116 & 40.18 & Concubines and Prisoners of War \\
\hline 3 & 368055 & 802076 & 9.34 & 37 & 49.53 & End-Time Wars \\
\hline 4 & 346031 & 362490 & 4.22 & 63 & 53.75 & Non-Combatant Martyrs \\
\hline 5 & 228394 & 294373 & 3.43 & 44 & 57.18 & Purpose and Excellence of Jihad \\
\hline 6 & 190049 & 382424 & 4.45 & 27 & 61.63 & First Civil War \\
\hline 7 & 168727 & 168727 & 1.97 & 6 & 63.6 & Apostasy \\
\hline 8 & 136181 & 185628 & 2.16 & 11 & 65.76 & Financial Issues \\
\hline 9 & 135233 & 234791 & 2.73 & 36 & 68.49 & Dhimmis \\
\hline 10 & 113257 & 193321 & 2.25 & 25 & 70.75 & Women's Jihad \\
\hline 11 & 111352 & 111352 & 1.3 & 12 & 72.04 & Virtues of the Companions \\
\hline 12 & 106357 & 134107 & 1.56 & 17 & 73.61 & Historical Wars \\
\hline 13 & 92458 & 255648 & 2.98 & 37 & 76.58 & Different Forms of Jihad \\
\hline 14 & 85706 & 347164 & 4.04 & 16 & 80.63 & When Jihad becomes Obligatory \\
\hline 15 & 68368 & 102086 & 1.19 & 24 & 81.82 & Political Issues \\
\hline 16 & 46285 & 98114 & 1.14 & 14 & 82.96 & Espionage \\
\hline 17 & 36875 & 76551 & 0.89 & 15 & 83.85 & Living among non-Muslims \\
\hline 18 & 32171 & 81945 & 0.95 & 12 & 84.8 & Martyrs \\
\hline 19 & 30820 & 37735 & 0.44 & 13 & 85.24 & Jihad vs. Family \\
\hline 20 & 29097 & 80426 & 0.94 & 4 & 86.18 & Fighting During the Sacred Months \\
\hline 21 & 26775 & 35377 & 0.41 & 11 & 86.59 & Helping the Infidels \\
\hline
\end{tabular}




\begin{tabular}{|l|l|l|l|r|r|l|}
\hline 22 & 25085 & 25085 & 0.29 & 1 & 86.89 & Prayers to Say during Distress \\
\hline 23 & 24464 & 24464 & 0.28 & 2 & 87.17 & Damages and Compensations \\
\hline 24 & 24133 & 24133 & 0.28 & 6 & 87.45 & Entertainment \\
\hline 25 & 22539 & 44396 & 0.52 & 13 & 87.97 & Prayers During War \\
\hline 26 & 20914 & 67388 & 0.78 & 6 & 88.75 & Some Verses on Jihad \\
\hline 27 & 20138 & 20138 & 0.23 & 7 & 88.99 & $\begin{array}{l}\text { Promotion of Virtue and Prevention } \\
\text { of Vice }\end{array}$ \\
\hline 28 & 20048 & 20048 & 0.23 & 1 & 89.22 & Impermissible Marriages \\
\hline $\mathbf{2 9}$ & $\mathbf{1 9 9 3 8}$ & $\mathbf{5 1 4 2 0}$ & $\mathbf{0 . 6}$ & $\mathbf{1 6}$ & $\mathbf{8 9 . 8 2}$ & Impermissible Occupations \\
\hline 30 & 18336 & 18336 & 0.21 & 1 & 90.03 & Zakat \\
\hline
\end{tabular}

Within this category, most questions are about concubinage. This subcategory has 96 questions and all of them ask more or less the same question: "Is it permissible to have sex with an enslaved woman?" Although we have no clear demographic data, the majority of the questioners seem to be males. The fatwas can be summarized in the ruling that this practice is permissible. However, since there are currently no lawful concubines, this question should not preoccupy Muslims and they should be occupied with more serious matters. Some questioners are concerned about this subject because of its effect on the reputation of Islam in general. One such questioner asks:

The enemies of this (Muslim) nation keep looking for anything that can drive people away from Islam, and their last poisoned arrow is the topic of having sex with concubines. They say that it is just another way for Muslims to rape women in wartime. How can we reply to this claim? (ID: 39093). ${ }^{32}$

Another asks:

I have a dear friend who, around two years ago, began to drift away from the Muslim religion. He now sees Muslim conquests as illegitimate since they were aggressions on others, and that we would not welcome being conquered, so why should non-Muslims welcome Muslim conquests? The more critical issue he raises is how can Muslim conquerors capture women and have legitimate sex with them (as authorized by Sharia) while we would not want our enemies to do this to our women if they defeated us. He said to me: "Would you be pleased if the victorious enemy captured your mother or sister and had sex with them? If you do not like this, how can you like it for the women of your enemy? Are they not sisters, wives, and mothers for men who would not want this?" I personally am convinced that Islam does not allow what is not in the best interests of people, and I'm also convinced that the Islamic conquests were mainly to spread the religion of Allah, and that those who answered the call of Allah were not fought. However, my friend still insists on the religious freedom of others, and that their land cannot be occupied even if they refuse the religion (of Islam), and that only Allah can hold them accountable. Please explain to me how I can reply to my friend concerning both the conquests and the permissibility of having sex with the females captured in battles and conquests. May Allah bless you (ID: 181549). 


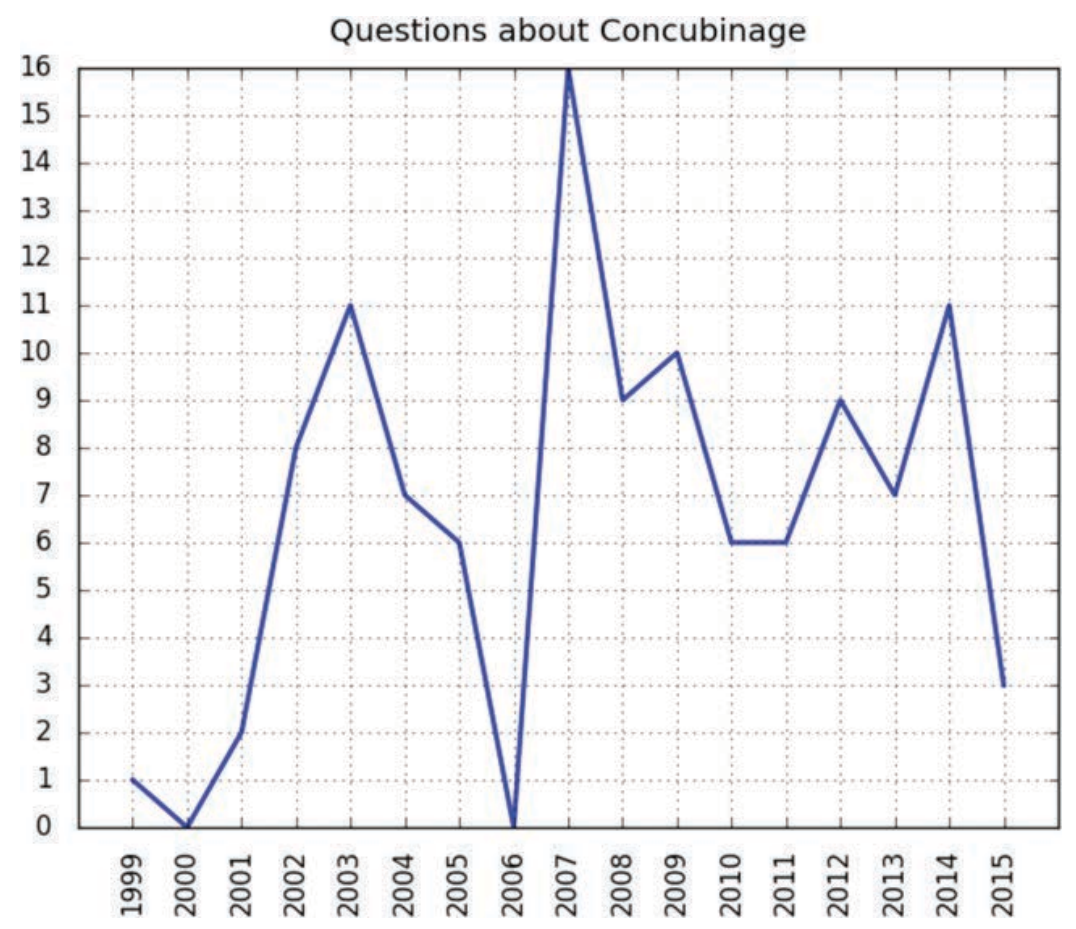

It is curious that the question of concubinage figures so highly among jihad questions, especially given that concubines, in the opinions of the muftis on the IWFC website, no longer exist. But while concubines may not exist, the desires behind their existence still do. In an article in the New York Times, Kamel Daoud explains: "Today sex is a great paradox in many countries of the Arab world. One acts as though it doesn't exist, and yet it determines everything that's unspoken. Denied, it weighs on the mind by its very concealment. Although women are veiled, they are at the center of our connections, exchanges and concerns." ${ }^{33}$

Even in questions about the Hereafter, sex is prominent. No less than 127 jihad questions about the Virgins of Paradise. ${ }^{34}$ This question is very popular and the fatwas on this topic have an average of 7,904 views per fatwa.

Also related to the question of concubinage are those on prisoners of war. Most often one finds general questions such as, "How did the Prophet treat Prisoners of War?” (ID: 17294). Sometimes there are more specific questions such as, "Is it permissible to pay a ransom to get a Muslim POW released by the Communists?" (ID: 32602). Another questioner asks, "Is it permissible for a POW to commit suicide if he is subjected to torture?" (ID: 29976). There are also the questions that contest the classical rulings about prisoners of war in Islamic law, including the following, which was asked in 2009: 
I have two questions:

First, what is the definition of captives in Islam? Were all the women in conquered cities captives? How were things in Andalusia when Musa b. Nusayr conquered cities with hundreds of thousands of people? It is certain that not all of these were captives?

Second, Christians were previously repressed in their lands; they did not own land and they paid high taxes. They were poor and not free. The Muslim conquerors were thus helped by those people and they welcomed the conquests and embraced Islam. Now, however, Europeans live in material and technological luxury, and enjoy absolute freedom of conduct. Their rights, and even the rights of their animals, are taken care of and they feel safe. Suppose there were an Islamic state today, and we were about to conquer a European state, how would the Muslims treat the people in that state? (ID: 126405).

In response to the first question, the muftis advise the mustafti to invest his time in more important topics than the rights of enslaved captives, which is of no use nowadays. In response to the second question they write:

\begin{abstract}
Islam is all light and virtue, and its message is not confined to ridding other peoples of repression. It is a comprehensive message and a universal mercy that aims at saving people from worshiping mankind and urging them to worship the Lord of Mankind. This message delivers people from the narrowness of this life to ease in this life and the Hereafter, and from the wrongdoing of [false] religions to the justice of submission.
\end{abstract}

With this questioner, the muftis thus practically evade both questions and dismiss them as irrelevant in the modern context. One reason for this evasion may be that the muftis are Salafi Muslims, who do not believe in abrogating or abolishing previously accepted Islamic practices. This notion is confirmed by another fatwa (ID: 18713), in which the muftis write, "It is not true that slavery in Islam has ended. The system of slavery in Islam has not ended [in a de jure sense]; however, it has ended in practice due to the fact that this was imposed by international organizations and world institutions."

\title{
(3) End-Time Wars
}

On October 3, 2014, William McCants of the Brookings Institute published an article on the village of Dabiq titled, "ISIS Fantasies of an Apocalyptic Showdown in Northern Syria," in which he reported that ISIS "fought ferociously to capture the village this summer because its members believe the great battle between infidels and Muslims will take place there as part of the final drama preceding the Day of Judgment." ${ }^{35}$ Because of this belief, Dabiq is the title of the ISIS online magazine. However, as it turns out, followers of ISIS are not the only ones interested in the end-time wars. This topic interests many Muslims, as evidenced 
by the fact that 37 questions on this subject can be found on the IWFC website, making up $9.34 \%$ of all jihad question views.

Questioners inquire about the wars that are believed to break out between Muslims and non-Muslims before the Day of Judgment. The figure of the Mahdi is prominent here, and a recurrent theme is the role of technology in the EndTime Wars, especially since hadith accounts state that the wars will be fought with swords and spears on horsebacks. Another theme is that of war between Muslims and Jews. The fatwas to these questions maintain that the war between the Jews and the Muslims will take place after the Muslims have achieved victory over the Christians. A sample question reads:

\footnotetext{
Is it true that during the End Times, stones and trees will tell on the Jews hiding behind them? What's the origin of this story? Is it true that God is angry with the Jews because they challenge him? And is it true that the Jews are known to be people of knowledge, in spite of God's being angry with them? (ID: 117386).
}

The muftis answer these questions in the affirmative and provide textual evidence from the Prophetic traditions to back up their opinions.

\section{(4) Purpose and Excellence of Jihad}

This is the fifth category listed in Table 1 . There are 44 fatwas under the category of Purpose and Excellence of Jihad, and questions on this topic make up $3.43 \%$ of the total views. The most obvious question in this category is how jihad can make Muslims great again, followed by how jihad can be useful for mankind in general. We also find questions on how Muslims can achieve victory in their military conflicts, questions about whether "financial jihad" is equal to sacrificing oneself in battle, questions about why the Islamic conquests have stopped, and questions on whether converting people to Islam is one of the virtues of jihad. The response usually given to these questions by the muftis is that the purpose of jihad is to put the world under the control of the Islamic shari'a, which makes it easier for people to be guided to Islam. However, forcing people to convert to Islam is not permissible, since "Jihad in Islam is not meant to enter faith in the hearts of people, it is meant to subject people to the rule of Islam, which may then be a reason for their heart-felt belief in Islam." (ID: 289408).

In this section, we find the only question in which a questioner is not a Muslim: "I am Christian, and I have a question that stands between me and embracing Islam. The Qur'ān states that 'there is no compulsion in religion,' and in another verse commands that non-believers be killed. How do you explain this? Is this not a contradiction?" (ID: 76362). The answer of the muftis is that forcing people to embrace Islam is not permissible. Then they urge the questioner to embrace Islam. They do not, however, answer the question directly. 


\section{(5) Dhimmis}

This is the ninth category in Table 1 above. This category discusses the conditions of non-Muslims who have reached a "peace-agreement" with Muslims in an Islamic polity, assuming the Muslims' victory in war. The major theme of these questions is the jizya (poll-tax). One question in this category reads:

\footnotetext{
If glory returned to Muslims and we began to rule with God's law, then started conquering nations, and we conquered a Buddhist country, would we take the jizya from them, or would they only have the choice between accepting Islam or getting killed? What legal evidence is there for this? And isn't this inconsistent with the verse in the Qur'ān that says: “There is no compulsion in religion?” (ID: 209560).
}

The mufti's response to this question is that there is a wide range of legal opinions on the matter. However, he is of the opinion that the people from whom jizya can be taken are not only People of the Book (Christians and Jews). Idol-worshipers such as Hindus and Buddhists can also pay the poll-tax.

Another question in this category is whether it is permissible to steal money from unbelievers as a form of jihad. The proposed justification for this is that although Muslims may not be at war with the unbelievers currently, their money will add to their potential strength. One questioner in this category asks:

\footnotetext{
I'm an accountant, and I market an American accounting software. I have been approached by local companies who offered me money in return for selling pirated copies of this software to them, saying that because the software is owned by our enemies, what I do is jihad against them. I believe that this is wrong, and that I cannot sell what I do not own. Can you provide me with legal evidence [on this subject], from the Qur'ān and the Sunna? (ID: 74685).
}

The muftis reply that the questioner is right, and that it is impermissible to cheat the company that produces the software. In support of their answer they also provide the questioner with a detailed set of legal evidence.

\section{(6) Women's Jihad}

This is the tenth most popular topic in Table 1 above. In response to the generic question, "What is the role of women in Jihad?" (ID: 8587), the muftis explain that while women can take part in war, they are usually not required to do so. However, they can perform other forms of jihad. Other forms of jihad include Verbal Jihad (through media and discussions) and Financial Jihad (contributing to the war effort). The muftis all agree that a woman who dies in battle is a martyr. However, throughout their fatwas, they discourage women's participation in war and war-related activities.

Another important theme in this category is whether women are allowed to work in the military field. While the muftis see no harm in women learning to use weapons and the martial arts, they object to women working in the military 
in combatant roles. For example, in a reply to a female aerospace engineering officer who asked their opinion about women piloting warplanes, the muftis advised her to quit her job, as it is unbefitting to a Muslim woman (ID: 67564).

\section{(7) Different Forms of Jihad}

As evidenced by the above question about alternative forms of jihad for women, $3.67 \%$ of questions and $2.98 \%$ of readers' views are about the different forms of jihad. While militaristic jihad is treated as the default type, questioners ask about alternative forms as well. The most viewed question in this category asks whether one who donates money for jihad will be rewarded by Allah the same way as a mujahid will be (ID: 16118). The muftis reply that this is indeed the case and cite the Prophetic tradition, "He who provides for a warrior is a warrior." Other questioners ask whether preaching Islam in the land of unbelief (dar al-kufr) is a form of jihad, and whether writing tracts against the enemies of Islam is also considered jihad.

It is here that one finds discussions of emerging forms of jihad as well. Two questions were on electronic jihad. In the first (ID: 12161), the questioner asks for a ruling on sabotaging the electronic networks of the enemy. In this case, the enemy is understood to be Israel, since the question also mentions settlements. The muftis reply that this is indeed a form of jihad, although they couch their answer in generic terms. The other questioner (ID: 33196) asks, "I am an Egyptian journalist. Would you please tell me what is the ruling on e-Jihad warriors who attack the websites that assail Islam, and what is the ruling on e-piracy of the websites that defame our religion?" To this, the muftis reply that cyber warfare is one of the greatest ways to get closer to God, since "it is known that the websites that attack Islam use fraud, deceit and lying in what they attribute to Islam and the Muslims."

\section{(8) When Does Jihad Become Obligatory?}

The most important question in this category asks: "Who is required to join jihad in the cause of Allah, and who is exempted?" (ID: 7730). This question alone has $80 \%$ of the views in this category. The scholars/muftis provide the classical answer that when a Muslim abode is attacked, jihad is incumbent on everyone present in that location. Other than that, for a person to be required to join jihad, he must be a mature, able-bodied, Muslim male who has a sound mind. Those exempted from jihad include youths whose parents have not given them permission to join jihad and those who are in debt, since paying debts has priority over waging jihad.

\section{(9) Espionage}

There are 14 questions on espionage in the fatwa corpus, viewed 98,114 times. The views of the scholars/muftis on espionage is that it is not permissible, even 
when one suspects that something is wrong because there is ample evidence in the Qur'ān and the hadith against it. Espionage may, however, be permitted under very specific conditions and should be sanctioned only by the highest political authority. The most viewed question is a generic one, which asks for a general ruling on espionage in Islam. Other, more specialized questions are concerned with the mandated Islamic punishments for a spy who works for the enemies of Islam. To this question, the muftis reply that there is a difference of opinion among Islamic scholars on whether a spy should be executed. Other questions ask about how a Muslim can spy on the unbelievers if he has to stay away from sex, drinking, and the other Western habits, and questions about spying on a non-Muslim state for another non-Muslim state in return for money. One question that is relevant to Muslims living in the West is as follows:

I've lived in Europe for eleven years, I've been a frequent mosque-goer for seven years, after God granted me repentance. I have found that a number of Arabs, including imams and mosque officers, and some non-Arab Muslim converts and others, spy on Muslims for the local authorities. Is it permissible to spy for the police under the pretext that it is just a job like any other job? (ID: 162145).

The muftis respond that such a scenario is not permissible. In addition, they discourage another questioner from joining a national spy agency since such a job entails "un-Islamic conduct" (ID: 27163).

\section{(10) Living in Non-Muslim Lands}

This category revisits a jihad-related question that has been asked of muftis since medieval times: Can a Muslim live as a minority in a non-Muslim country? A modern version of this question asks whether a Muslim can obtain the citizenship in a non-Muslim country. The rather surprising answer given by the IWFC scholars/muftis is that except in dire circumstances, a Muslim should not live in a non-Muslim country. However, since many Muslims live in non-Muslim countries today, they may be subjected to certain situations that would not be found in their original countries. A Muslim living in Denmark asks:

I have lived in Denmark for the past 9 years, and as you know, we are under a lot of pressure because we are Muslims. I used to bear this and wish for relief from Allah, as I am a simple, powerless person. Then they made those horrible cartoons of the Prophet Muhammad. The government and the people wanted that, and they wanted to humiliate Muslims in every way possible. I got mad, and decided to make them pay a price for what they did. Two years ago, I started stealing things from them, knowing they could not find me out. I know that stealing is not permitted by Islam and that it is punishable in this life and in the hereafter, but I took it as a [state of] war between us. I would steal from them, add money from my own, and distribute the money to the poor in my country of Lebanon. Please give me a fatwa on this. If what I'm doing is wrong, how can I repent? (ID: 114110). 
The muftis tell the questioner that what he has been doing is impermissible. In addition to the fact that stealing is a crime in Islam, the muftis explain that a Muslim in a non-Muslim land has signed a de facto contract to respect their laws. Through his behavior, the questioner has not respected this de facto contract. The muftis then advise the questioner to return the money, even secretly, to the people he took it from.

\section{(11) Jihad Versus Family Obligations}

Thirteen questions in the sample ask more or less the same question: "Which is more favored by God: to take care of my relatives or join jihad?" In these questions, the term, "relative" could mean children, parents, sisters, or a sick wife. While details of the fatwas may vary, the general principle followed is that the permission of one's parents is required for joining jihad. Taking care of a sick wife is also an excuse for not joining jihad, as is the responsibility to care for small children.

\section{Results and Discussion II: Who Is Jihad Directed Against?}

Because the concept of jihad is religious in nature, and it is only natural that conflict with other religions is a common topic in jihad questions. In the sample studied for this article, 108 questions contained references to Jews, Christians, Hindus, and Buddhists. Jews are the largest group mentioned and are found in $73 \%$ of the questions, followed by the Christians (34\%), Hindus (3.7\%), and Buddhists (3.7\%). ${ }^{36}$

In fact, in the entire IWFC fatwa corpus, Jews are more frequently referred to than Christians, or any other religion for that matter. While Christians are referred to 5,330 times, Jews are referred to 7,507 times. In general, Jews are viewed negatively. This has both theological and political reasons. The Qur'ān describes Jews as "a people who made a covenant with God, whom God favored above all other nations, who denied God's signs, whose hearts have been hardened or are uncircumcised, and who kill the prophets." ${ }^{37}$ These traits mentioned in the Qur'ann are also emphasized in the fatwas. In recent history, the Palestinian-Israeli conflict led 850,000 Jews to leave their homes in Arab countries, and 726,000 Palestinians to leave their homes in Palestine. $^{38}$

In the 79 jihad questions about Jews, history is the most prominent theme, as $46 \%$ of the questions are about the Prophet Muhammad's wars against the Jews. The question of Palestine comes next, in $23 \%$ of the questions. Common questions asked about the Jews include the following: What steps should be taken if the Jews destroy the al-Aqsa Mosque to build Solomon's Temple? Are Palestinians are required to fight the Jews even if Jews are not armed? Is 
every Israeli soldier a legitimate target, or only those that attack Muslims? Are all Muslims required to defend Palestine, or is it only a Palestinian duty? Are Palestinians killed by friendly fire considered martyrs? Is the use of publicity to expose the actions of Jews and Israelis to the world a legitimate form of jihad? Among these questions, the End-Time Wars between Muslims and Jews make up $11 \%$ of the total number.

Because of considerations of space, we will discuss in detail only the Palestine-Israel issue. The Palestinian-Israeli conflict may have started as a political conflict, but " $[\mathrm{m}]$ ost recently and with seemingly increasing assent, the conflict has become wrapped around religious principles ostensibly providing fertile ground for a zealotry that translates all notions of compromise into violations of sacred commandments." ${ }^{39}$ This reality is strongly reflected in the jihad questions that Muslims ask on the IWFC website.

In questions involving Palestine, one can spot four major themes: (1) fighting against Israel as a form of jihad; (2) questions about the permissibility of doing business with Israelis or Jews; (3) supporting Palestine through different forms of jihad; (4) the role of women in the jihad against Israel. The most viewed question in this category - and one of the oldest, going back to 2001(ID: 8509) - asks: "What is the ruling on Jihad in Palestine?" The ruling of the muftis on this question is that jihad for the sake of Palestine is fard 'ayn (an individual obligation on every Muslim who is able to participate in jihad). Many other questions are related to this topic, including those that discuss the fight against the Jews either currently or in the End Times.

The question of doing business with Jews or Israelis comes next. A common question in this category is: "The Jews and Israelis are our enemies, but I work in a field where I have to deal with them instead of fighting them. What can I do?" A similar question to this comes from a woman who asks whether she should destroy a product that she bought online, not knowing that it was produced by a company in Israel (ID: 168945). The response of the scholar/mufti is that she should not destroy the product, but that she should refrain from buying the product in the future.

On supporting Palestinians through different forms of jihad, a Muslim who lives in Belgium tells the muftis that he is a student of Middle Eastern Studies, and asks whether it would be considered jihad if he focused on exposing Israel and the Jews to the Belgians (ID: 119316). The muftis respond that exposing what happens to the children of Gaza and Jerusalem through publicity or scholarship is a form of jihad. At the end of their fatwa, they remind the questioner that a Muslim should restrict his dealings "with atheists and even delinquent Muslims to showing them the truth and calling them to it. He should not be friends with them, since your friends determine who you are." 
Women ask many jihad questions about Palestine too. A mother of two from Egypt asks, "Can I leave my two children with their father and go to Palestine to carry out a martyr operation for the sake of the al-Aqsa Mosque? (ID: 227443)." In their answer, the muftis express appreciation for her desire for jihad, but advise her to support the Palestinians financially since this is what they need the most. Another woman, a doctor, asks whether she can go for service and jihad in Palestine without a male guarantor (mahram), since she wants to die as a martyr:

I am an Arab doctor, not satisfied with myself, and I feel I'm very psychologically weak. I do very few good things, and I have a lot of sins. I fear I could die in such a state, so I thought of traveling to Palestine for both work and jihad. [In Palestine] I could be in a good environment and close to people's suffering, in order to help them. I wish to die as a martyr so I may not be held accountable for my previous sins. Is it permissible for me to do so? Please note that I am not married, and I will not be accompanied by a mahram. Is it necessary to have a mahram if your intention is to travel to an Arab country for jihad?

In this case, the muftis give a similar fatwa to that given to the previous woman.

One highly viewed question in this category asks, "Is a hunger strike an Islamically legitimate weapon that Palestinian prisoners can use against the Zionist enemy? And if a prisoner dies because of this, is he considered a martyr?" (ID: 181937). This is one of very few questions in which the muftis cite the Egyptian scholar Yusuf Al-Qaradawi, whose fatwa is that a hunger strike is a legitimate weapon of jihad as long as it does not lead to death. Although the muftis show support for Qaradawi's opinion, they also state that Islamic scholars do not support his ruling unanimously.

Miscellaneous questions about Jews and jihad include questions about the permissibility of waging electronic jihad against the Jews, and whether stealing Jewish money is considered jihad. There is even a question from someone, apparently Palestinian, who asks that because the Jews have raped Muslim women, is it permissible for him to also rape Jewish women in retaliation? (ID: 23483)..$^{40}$ The end time battle of Armageddon also seems to occupy much interest for at least some questioners and it is portrayed as a battle between the Muslims and the Jews.

By contrast, Christians do not seem to pose a major threat to the questioners. Most of the questions that involve Christians are of a historical or generic nature. The same holds true for Hindus. Buddhists are mentioned only four times: once in a question about the status of Muslims in Myanmar (formerly Burma), and three times in generic jihad questions. One question is so odd that it is worth repeating here in full:

There is a Prophetic tradition that renders fitna (causing enmity) impermissible. However, it is a generic hadith, so am I allowed to ignite enmity and rifts among 
the disbelievers so that they fight amongst themselves, and not against Muslims? Sometimes, I pose as a non-Muslim, and ignite rifts among the Westerners. For example, I play them against each other in football, or play the Jews, Hindus, and Christians against one another so that war may break out between them in the future. This way we can get rid of them. Is what I am doing impermissible? Should I stop this? (ID: 267313).

The muftis advise the questioner to stop what he is doing as this kind of trickery is permitted only during wartime.

\section{Conclusion}

In this article, we have presented an overview of the jihad questions that Muslims ask on the IWFC fatwa website. Although we have tried to present as much information as possible, because of space limitations we could only focus on the overall picture and not on the fine details. As stated in the Introduction, we have also focused more on the questions than on the answers given to them. Each category of questions presented above requires more profound analysis, and giving each topic its due analysis would require more space than can be provided here. However, we can conclude that the majority of the jihad questions asked on the IWFC website are broadly consistent with those asked in medieval times. Apart from the main interest being historical, the questions asked about concubines, the enslavement of captives, the abode of Islam versus the abode of unbelief, and many others seem to indicate either a longing for the "good old days" of the Muslim Empire, or, in more limited cases, objections to these medieval concepts. The question of Palestine is one of the few modern issues to have been raised, yet this too is not free from medieval overtones, especially since the opponent in this case is the Jews, who have long played an important role in both the history of jihad and in traditions about the End-Time Wars.

While we have tried in this study to introduce methods of digital humanities and quantitative analysis to the field of fatwa studies, we also know that the present study is not without drawbacks. One aspect of this study that might be improved in the future is question classification. For the sake of simplicity, we assigned each question to only a single category. We assigned to the question the category we thought was most relevant, using, in the majority of cases, the categories provided by the IWFC website. In reality, though, each question could have been assigned to several different categories. For example, when a woman asks, "Which is better for a Palestinian: fighting the Jews militarily, through media, or just focusing on building our scientific capacities so we may be able to liberate our country in the future?" this question could be classified as "Jihad against the Jews," 
"The Palestinian-Israeli Conflict," "Non-Military Jihad," "Women's Jihad," and possibly many other things as well.

Another topic that could have been explored further was the question of jihad motives. While most questions do not have an expressly stated motive, much can be learned from the few that do. For example, one questioner asked, "I have been a mental patient for the last thirteen years. I have a terrible case of depression and my life is on the margin. What is your opinion on my joining jihad in order to get rid of my life and get a better one?" (ID: 215626). In this case, the scholars/muftis encouraged the questioner to join jihad. Obviously, this raises important ethical and psychological issues, especially because this question was not unique. Other questioners wanted to join jihad to expiate their perceived sins, which ranged from homosexuality to not observing the Islamic prayers. This issue deserves a study of its own, but we must leave it for future research.

Something that we wanted to do in this study but found difficult was to classify the people who asked the following questions. What kinds of Muslims ask which kinds of questions? Does age play a part? Is gender an influential factor? Does it matter where the person lives? Is income level related to one's interest in jihad? Unfortunately, all of these questions require data that we were unable to obtain. ${ }^{41}$ If we had access to this data, it would have provided a much fuller picture of the sample population, whose surface we have only scratched.

While surveys may be a good way of obtaining preliminary data, detailed surveys are expensive and difficult to conduct so most researchers use smaller samples like this one. For example, a study of the motivations of sacred violence in Indonesia surveyed 934 subjects and found that only belief in violent jihad was a clear predictor of sacred violence. Religiosity, fundamentalism, support for Islamic law, or perceptions of unfair treatment did not seem to have a bearing on the adoption of sacred violence. On the contrary, piety and the practice of religious rituals were negatively correlated with violence. ${ }^{42}$ By contrast, another study that surveyed both Iranians and Indonesians found religiosity to be the main motivator for jihad, where religiosity was defined as an emotional trait. Knowledge of Islam and ritual practices were found not to be significant. ${ }^{43}$ This study was in line with the famous Gallup study of "Who Speaks for Islam?" We believe that with different questions and more data, either original or computationally inferred, we should be able to mitigate the shortcomings of current jihad research.

\section{Endnotes}

1. ElSayed Amin, Reclaiming Jihad: A Qur'ānic Critique of Terrorism (Markfield, UK: The Islamic Foundation, 2014), 80. 
2. L.J. Kraemer, "Maimonides' Use of (Aristotelian) Dialectic," in Maimonides and the Sciences, eds. R. S. Cohen and K. Gavroglu (Dordrecht, NL: Kluwer Academic Publishers, 2001).

3. Ibn Qayyim Al-Jawziyya (1292-1350 ce) was a student of Ibn Taymiyyah. He edited, defended, and propagated his teacher's books and views, and was persecuted and imprisoned, along with Ibn Taymiyya for his views. He wrote prolifically on theology and Islamic law, and has had a profound influence in Salafi and Wahhabi traditions. Ibn Al-Qayyim is the second most cited scholar in Jihad fatwas.

4. Bernard Lewis, The Political Language of Islam (Chicago: University of Chicago Press, 1988), 72.

5. Oxford English Dictionary, s.v. "Jiahd," http://www.oxforddictionaries.com/us/definition /english/jihad (Accessed January 1, 2017).

6. Wael B. Hallaq, Sharia: Theory, Practice, Transformations (Cambridge, UK: Cambridge University Press, 2009), 324.

7. Emad Mohamed, "Jewish, Christian, and Islamic in the English Wikipedia," Heidelberg Journal of Religion on the Internet 11 (2016): 116-137.

8. Langviews Analysis is a website that provides how often a Wikipedia page is accessed: https://tools.wmflabs.org/langviews/ (Accessed August 1, 2016).

9. Pew Research Center, “Most visited Wikipedia articles by language in 2015," http://www .pewresearch.org/2016/01/14/wikipedia-top-10/ (Accessed August 1, 2016).

10. Alexandre Caiero, "The Making of Fatwa: The Production of Islamic Legal Expertise in Europe," in Archives de Sciences Socials des Religions 155 (2011): 81-100.

11. Gary R. Bunt, Islam in the Digital Age: E-Jihad, Online Fatwas and Cyber Islamic Environments (London: Pluto Press, 2003).

12. G. Weimann, “Cyber-Fatwas and Terrorism," Studies in Conflict \& Terrorism, 34 (10) (2011).

13. Lewis, The Political Language of Islam, 78.

14. Ibn Taymiyyah (1263-1328 ce) is the most cited scholar in Jihad fatwas. He grew up in a time of turmoil in the Muslim world and witnessed the Crusades and Mongol invasion. He wrote a series of refutations against theologians, philosophers, Christians, Shiites, and Sufis. Ibn Taymiyyah is the main inspiration behind the Wahhabi movement as well as many modern revivalist schools.

15. Amin, Reclaiming Jihad, 97.

16. Asmaa Afsaruddin, Striving in the Path of God. Jihäd and Martyrdom in Islamic Thought (Oxford: Oxford University Press, 2013), 4.

17. Muhammad 'Abduh was an Egyptian Islamic reformist who quit politics in favor of a mission for educating Muslims. 'Abduh was also Mufti of Egypt. His mission focused on the Qur'ān as the basis of reforms, and part of his project was introducing a new interpretation of the Qur'ān. His Qur'ān exegesis was followed on, after his death, by his student Rashid Rida. (Leaman, 2015, Biographical Encyclopedia of Islamic Philosophy, Bloomsbury).

18. Muhammad Rashid Rida (1865-1935) was Muhammad 'Abduh's main student and partner in the project of reviving Islam. He saw no incompatibility between Islam and modernity but was more cautious towards the West than 'Abduh. Al-Manar, the journal he established, was a very influential publication. The journal was taken over by Hasan Al-Banna (the General Guide of the Muslim Brotherhood Association) after Rida’s death.

19. This section is a very brief summary of the excellent discussion in Amin's Reclaiming Jihad, 79-125.

20. Mahmoud Shaltout, The Qur'ān and War (Cairo: Arab Book House, 1951), 36.

21. All statistics come from Alexa.com (Accessed January 29, 2016). 
22. See for example, http://www.dar-alifta.org/AR/ViewFatwa.aspx?ID=3760. The Egyptian Fatwa House website also often crashes, which makes it an unreliable source of information.

23. We used topic modeling as implemented in the Gensim package. R. Ǩehưrek and P. Sojka, Software Framework for Topic Modelling with Large Corpora. Proceedings of the LREC 2010 Workshop on New Challenges for NLP Frameworks. PP 45-50. Valletta, Malta. http://is.muni .cz/publication/884893/en/. (Accessed August 1, 2016).

24. Boris Iglewicz and David Hoaglin, "How to Detect and Handle Outliers," in The ASQC Basic References in Quality Control: Statistical Techniques, vol. 16, ed. Edward F. Mykytka.

25. Throughout this paper, we will refer to fatwas by their ID number. Fatwas can be found by their ID on the Islam Web Fatwa Center website: http://fatwa.islamweb.net/fatwa/index.php.

26. David Cook, Understanding Jihad (Berkeley, CA: University of California Press, 2005), 2.

27. Hallaq, Sharia, 331.

28. Norman York, "Concubinage" in Medieval Islamic Civilization: An Encyclopedia, ed. Josef W. Meri (London: Routledge, 2005).

29. Muhammad Abu-Zahra, International Relations in Islam (Cairo: Arab Thought House, 1995), 123.

30. Fawwaz Gerge, ISIS: A History (Princeton, NJ: Princeton University Press, 2016), 31.

31. See: Lori Hinnant, Maya Allezeruzzo, and Balnit Szlanko, "ISIS Tightens its Grip on 3,000 Sex Slaves," The Associated Press (New York), July 5, 2016, http://www.cbc.ca/news/world/isis -women-sex-slaves-1.3666253 (Accessed August 1, 2016).

32. The fatwas are originally in Arabic. Unless otherwise indicated, all the translations in this article are our own.

33. Kamel Daoud, "The Sexual Misery of the Arab World," The New York Times (New York), February 12, 2016, https://www.nytimes.com/2016/02/14/opinion/sunday/the-sexual-misery -of-the-arab-world.html?_r=0 (Accessed August 1, 2016).

34. The Virgins of Paradise is an English rendering of the Arabic hur ein, which is generally held to mean "women, who have wide eyes with a marked contrast of intense white and deep black," and are a reward promised to believers in the Paradise. See: Setfan Wild, "Paradise," in The Qur'ān: An Encyclopedia, ed. Oliver Leaman. (London: Routledge, 2006).

35. William McCants, "ISIS Fantasies of an Apocalyptic Shutdown in Northern Syria," Markaz (blog), October 3, 2014, https://www.brookings.edu/blog/markaz/2014/10/03/isis-fantasies -of-an-apocalyptic-showdown-in-northern-syria/ (Accessed August 1, 2016).

36. The numbers do not add up to $100 \%$ because some questions may have more than one target.

37. Gabriel Said Reynolds, "On The Qur'ān and The Theme of Jews as 'Killers of the Prophets," Al-Bayan: Journal of Qur'an and Hadith Studies, 10 (2012): 9-32.

38. Martin Gilbert, In Ishmael's House: A History of Jews in Muslim Lands (New Haven, CT: Yale University Press, 2010), 26.

39. D. R. Divine, "Palestinian-Israeli Conflict: A Contest in Word and Deed," in The Routledge Handbook of Muslim-Jewish Relations, ed. J. Florence Meri (London: Routledge, 2016).

40. The conflation of Israeli and Jewish is common in the fatwas, and sometimes only through contextual clues can be able to determine which one the question is about

41. This is confidential information that IslamWeb heavily guards. We have contacted them, but our efforts have so far failed.

42. Hamdi Muluk, Nathanael G. Sumaktoyo, and Dhyah Madya Ruth, "Jihad as Justification: National Survey Evidence of Belief in Violent Jihad as a Mediating Factor for Sacred Violence 
among Muslims in Indonesia," Asian Journal of Social Psychology 16 (2013): 101-111 DOI: 10.1111/ajsp.12002 (Accessed August 1, 2016).

43. Dicky Sofjan, Why Muslims Participate in Jihad: An Empirical Survey on Islamic Religiosity in Indonesia and Iran (Bandung, ID: Mizan Pustaka, 2006), 202.

44. John Esposito and Dalia Mogahed, Who Speaks for Islam? What a Billion Muslims Really Think (New York: Gallup Press, 2007), 65-98. 